Pediat. Res. 1: 452-460 (1967)

Ammonium chloride

kidney

acidosis renal function

hydrogen ion

clearance index

\title{
The Renal Response of Children to Acute Ammonium Chloride Acidosis
}

\author{
G.M. Edelmann, Jr. ${ }^{[37]}$, H. Borchis, J. Rodriguez Soriano and H.Stark
}

Department of Pediatrics, Albert Einstein College of Medicine, Bronx, New York, USA

\begin{abstract}
Extract
The present observations were undertaken to establish the response of children to the acute administration of ammonium chloride, in order to provide a basis for identifying and interpreting abnormalities in the mechanisms involved in renal acid base regulation. Fifty-eight normal children aged 4 to 13 years were studied before and for 5 hours following administration of ammonium chloride. Group A, consisting of 23 children, received $75 \mathrm{mEq} / \mathrm{m}^{2}$ body surface area or $2.75 \mathrm{mEq} / \mathrm{kg}$ body weight. Group $\mathrm{B}$, consisting of 35 children, received $150 \mathrm{mEq} / \mathrm{m}^{2}$, or $5.45 \mathrm{mEq} / \mathrm{kg}$.

Values for serum electrolytes, urea, creatinine, osmolality and acid-base parameters in children in Groups A and B are shown in tables I and III. Urinary pH and rates of excretion of titratable acid and ammonium are shown in tables II and IV. The relations between blood $\mathrm{tCO}_{2}$ and urinary concentration of $\mathrm{H}^{+}$, rate of excretion of titratable acid, and rate of excretion of ammonium for all subjects are shown in figures $1-3$. Progressively lower values of $\mathrm{pH}$ were observed over the entire range of $\mathrm{tCO}_{2}$ studied. During control periods, an inverse correlation was present between $\mathrm{tCO}_{2}$ and rates of excretion of both titratable acid and ammonium. At levels of $\mathrm{tCO}_{2}$ below $22.5 \mathrm{mmoles} / \mathrm{l}$, the rate of excretion of TA and ammonium became constant, with mean rates of excretion of $52 \mu \mathrm{Eq} / \mathrm{min} /$ $1.73 \mathrm{~m}^{2}$ (range, $\pm 2 \mathrm{SD}, 33$ to $7 \mathrm{l}$ ), and $73 \mu \mathrm{Eq} / \mathrm{min} / 1.73 \mathrm{~m}^{2}$ (46 to 100 ), respectively.

These data are interpreted as demonstrating the importance of the blood $\mathrm{tCO}_{2}$ or, more precisely, the concentration of bicarbonate in glomerular filtrate in urinary acidification mechanisms as well as in control of excretion of bicarbonate. Assessment of renal acidifying mechanisms requires administration of sufficient ammonium chloride or other acidifying substance to depress blood $\mathrm{tCO}_{2}$ to levels well below the renal threshold.

The physiologic validity of the hydrogen ion clearance index must be questioned, since correcting rates of excretion of hydrogen ion for concentration of total $\mathrm{CO}_{2}$ in blood presumes that there is a fixed relation between these two measurements. In figure 4, urinary excretion of total hydrogen ion is plotted as a function of blood $\mathrm{tCO}_{2}$. Hydrogen ion excretion, negligible at $\mathrm{tCO}_{2}$ levels of 26 or more, increases steadily as $\mathrm{tCO}_{2}$ falls to values below the threshold. The rate of excretion then reaches maximal levels, despite further reduction in blood $\mathrm{tCO}_{2}$. Thus, the hydrogen ion clearance index is valid only over the range of blood $\mathrm{tCO}_{2}$ in which there is a linear relationship with rate of excretion of hydrogen ion. Renal acidification mechanisms should be evaluated with blood $\mathrm{tCO}_{2}$ several millimoles below the threshold, assuring a maximal response and permitting direct comparison with normals. In subjects with a normal bicarbonate threshold, blood $\mathrm{tCO}_{2}$ should be depressed at least to $17-18 \mathrm{mmoles} / 1 \mathrm{in}$ infants and $20-21 \mathrm{mmoles} / \mathrm{l}$ in older children. If an abnormal bicarbonate threshold is present the dose must be adjusted accordingly.
\end{abstract}




\section{Speculation}

These studies suggest that both the concentration of bicarbonate in glomerular filtrate and the level of the bicarbonate threshold play major roles in the regulation of renal excretion of hydrogen ion.

\section{Introduction}

Excretion of acid in urine is accomplished by renal tubular secretion of hydrogen ion causing reabsorption of filtered bicarbonate and urinary acidification, with formation of titratable acid and ammonium. Urinary acidification and formation of titratable acid and ammonium in children are considered here. Tubular reabsorption of bicarbonate and excretion of acid in infants have been the subject of a separate report [4].

In order to investigate the response of the kidney to metabolic acidosis, the capacity to excrete hydrogen ion in response to various acidifying agents, such as hydrochloric acid, ammonium chloride and calcium chloride, has been studied repeatedly in the past four or five decades $[6,8,11]$. Most tests have required prolonged administration of ammonium chloride [5, 25]. The complexity and duration of these procedures have precluded their use in routine clinical investigation, particularly in infants and children, in whom only a few studies have been reported [7, 9, 17, 28].

Although Sartorius, Roemmeit and Pitts [29] had previously reported the renal response of a single subject to acute acidosis induced by a single dose of ammonium chloride, Wrong and Davies [3,34] were the first to describe in detail the short ammonium chloride loading test. This test seemed especially suited to exploration of renal regulation of acid-base balance in infants and children. The procedure does not require hospitalization; it can be completed in the course of a single day, and a severe degree of acidosis is avoided. The present observations were undertaken to establish the response of children to the acute administration of ammonium chloride in order to provide a basis for identifying and interpreting abnormalities in the mechanisms involved in renal acid base regulation.

\section{Materials and Methods}

Fifty-eight normal children, 4 to 13 years of age, were studied. All children were hospitalized for minor illnesses or for elective surgery. The latter were studied either before or at least five days after surgery, and no subject undergoing major surgery was included. Subjects with any type of renal disease or nonrenal disorder that might affect water and electrolyte or acid-base metabolism were excluded. All subjects were consider- ed to be healthy children and fell within the tenth and seventy-fifth percentiles for height and weight. The investigations were performed with institutional approval. Informed parental consent was obtained in every case.

Studies were performed in the renal unit and were begun uniformly between 8 and 9 a.m. The patients remained recumbent during the test, but were allowed free movement in bed. Breakfast was permitted on the day of the test, and a usual lunch was given at the appropriate time. In order to ensure an adequate and suitably constant rate of urine flow, water was administered throughout the test at the rate of $50 \mathrm{ml} / \mathrm{h} / \mathrm{m}^{2}$. Urines were collected at hourly intervals by spontaneous voiding. Urine specimens were not collected under oil but were examined immediately for $\mathrm{pH}$ and titratable acid and were stored for other determinations in air-free containers.

Arterialized capillary blood samples were collected in heparinized tubes for determination of $\mathrm{pH}, \mathrm{P}_{\mathrm{CO}_{2}}$ and total $\mathrm{CO}_{2}$ content. Blood specimens for other determinations were obtained from superficial veins during free flow.

Following collection of two 30- to 60-minute control urines, samples of venous and capillary blood were also obtained. Ammonium chloride was given by mouth over the course of the next hour; it was taken either in gelatin capsules by the older children or dissolved in water flavored with lemon juice and sugar in theyounger children. The ammonium chloride was well tolerated by most subjects, although a few vomited after receiving the first portion of the ammonium chloride. An equivalent amount of drug was given again, followed by the balance of the total dose, without further vomiting.

The dosage of ammonium chloride was as follows: Group A, consisting of 23 children, received $75 \mathrm{mEq} /$ $\mathrm{m}^{2}$ body surface area or $2.75 \mathrm{mEq} / \mathrm{kg}$ body weight. Group B, consisting of 35 children, received $150 \mathrm{mEq} /$ $\mathrm{m}^{2}$ or $5.45 \mathrm{mEq} / \mathrm{kg}$.

Following administration of the ammonium chloride, five urine samples with approximately 60 minutes between samples were collected in subjects in Groups $A$ and B, except that in some children in Group B, observations were discontinued after the third or fourth test hour. Blood samples were obtained three to four hours after the ingestion of ammonium chloride was completed. 
Analytical procedures employed have been described previously $[4,26]$. The hydrogen ion clearance index was calculated according to the formula proposed by Elrinton, Huth, Webster and MaCANce [5]:

Hydrogen ion clearance index $=\mathrm{UV}_{\mathrm{H}}+\times \mathrm{tCO}_{2}$ where $\mathrm{UV}_{\mathrm{H}^{+}}$is the net rate of excretion of hydrogen ion, estimated as the sum of titratable acid and ammonium minus bicarbonate, and $\mathrm{tCO}_{2}$ is the total $\mathrm{CO}_{2}$ content of blood.
Results $^{1}$

Values for electrolytes, urea, creatinine, osmolality and acid-base parameters of serum in children of Groups $A$

1 The following abbreviations are employed: total $\mathrm{CO}_{2}$ or $\mathrm{CO}_{2}$ content, $\mathrm{tCO}_{2}$; partial pressure of $\mathrm{CO}_{2}, \mathrm{PCO}_{2}$; base excess, $\mathrm{BE}$; titratable acid, TA; ammonium, $\mathrm{NH}_{4}^{+}$.

Table I. Group A. Blood values before and three to four hours after administration of $\mathrm{NH}_{4} \mathrm{Cl}, 75 \mathrm{mEq} / \mathrm{m}^{2}$

\begin{tabular}{|c|c|c|c|c|c|c|c|c|c|c|c|c|}
\hline & \multirow[t]{2}{*}{$\mathrm{pH}$} & \multirow{2}{*}{$\begin{array}{l}\mathrm{BE} * \\
\mathrm{mEq} / 1\end{array}$} & \multirow{2}{*}{$\begin{array}{l}\mathrm{tCO}_{2} \\
\text { mmoles/1 }\end{array}$} & \multirow{2}{*}{$\begin{array}{l}\mathrm{P}_{\mathrm{CO}_{2}} \\
\mathrm{~mm} \mathrm{Hg}\end{array}$} & $\mathrm{Na}$ & $\mathrm{K}$ & $\mathrm{Cl}$ & $\mathrm{Ca}$ & $\mathrm{P}$ & Urea & \multirow{2}{*}{$\begin{array}{l}\text { Osm } \\
\mathrm{mOsm} / 1\end{array}$} & \multirow{2}{*}{$\begin{array}{l}\text { Creatinine } \\
\mathrm{mg} / 100 \mathrm{ml}\end{array}$} \\
\hline & & & & & \multicolumn{4}{|c|}{$\mathrm{mEq} / \mathrm{l}$} & \multicolumn{2}{|c|}{ mmoles/l } & & \\
\hline $\begin{array}{r}\text { Control } \\
\text { mean } \\
\text { range }\end{array}$ & $\begin{array}{l}7.41 \\
7.35 \\
7.48\end{array}$ & $\begin{array}{c}+0.06 \\
-2.5 \\
+2.8\end{array}$ & $\begin{array}{l}25.1 \\
23.5 \\
27.2\end{array}$ & $\begin{array}{l}39 \\
33 \\
45\end{array}$ & $\begin{array}{l}141 \\
134 \\
150\end{array}$ & $\begin{array}{l}4.9 \\
3.7 \\
6.5\end{array}$ & $\begin{array}{r}103 \\
96 \\
109\end{array}$ & $\begin{array}{l}5.0 \\
4.3 \\
5.3\end{array}$ & $\begin{array}{l}1.6 \\
1.3 \\
1.9\end{array}$ & $\begin{array}{l}5.4 \\
3.2 \\
7.0\end{array}$ & $\begin{array}{l}280 \\
260 \\
295\end{array}$ & $\begin{array}{l}0.60 \\
0.43 \\
1.00\end{array}$ \\
\hline $\mathrm{n}$ & 23 & 23 & 23 & 23 & 23 & 22 & 23 & 21 & 22 & 22 & 22 & 15 \\
\hline $\begin{array}{c}\text { After NI } \\
\text { mean } \\
\text { range }\end{array}$ & $\begin{array}{l}\mathrm{H}_{4} \mathrm{Cl} \\
7.36 * * \\
7.29 \\
7.45\end{array}$ & $\begin{array}{l}-3.86 * * \\
-6.0 \\
-1.8\end{array}$ & $\begin{array}{l}21.6 * * \\
19.4 \\
24.6\end{array}$ & $\begin{array}{l}38 \\
31 \\
44\end{array}$ & $\begin{array}{l}141 \\
132 \\
149\end{array}$ & $\begin{array}{l}4.9 \\
4.0 \\
5.9\end{array}$ & $\begin{array}{l}108 * * \\
102 \\
115\end{array}$ & $\begin{array}{l}* 5.0 \\
4.55 \\
5.25\end{array}$ & $\begin{array}{l}1.7 \\
1.3 \\
2.2\end{array}$ & $\begin{array}{l}6.3 * * \\
2.7 \\
8.6\end{array}$ & $\begin{array}{l}282 \\
268 \\
295\end{array}$ & $\begin{array}{l}0.62 \\
0.39 \\
0.80\end{array}$ \\
\hline $\mathrm{n}$ & 23 & 22 & 22 & 22 & 23 & 22 & 22 & 21 & 22 & 22 & 15 & 22 \\
\hline
\end{tabular}

* BE: Base excess

** Significantly different from control $(\mathrm{p} \leqq 0.01)$

Table II. Group A. Urinary hydrogen excretion in hourly collections before and after administration of $\mathrm{NH}_{4} \mathrm{Gl}$, $75 \mathrm{mEq} / \mathrm{m}^{2}$

\begin{tabular}{|c|c|c|c|c|c|c|c|c|}
\hline & \multirow[t]{2}{*}{ Periods } & 1 & 2 & 1 & 2 & 3 & 4 & 5 \\
\hline & & \multicolumn{2}{|c|}{ Control } & \multicolumn{5}{|c|}{ After $\mathrm{NH}_{4} \mathrm{Cl}$} \\
\hline \multirow[t]{4}{*}{$\mathrm{pH}$} & mean & 6.46 & 6.51 & 5.33 & 5.16 & 5.11 & 5.15 & 5.11 \\
\hline & range & 5.07 & 5.2 & 4.9 & 4.77 & 4.65 & 4.7 & 4.7 \\
\hline & & 7.7 & 7.43 & 6.05 & 5.9 & 5.85 & 5.95 & 5.9 \\
\hline & $\mathrm{n}$ & 19 & 22 & 23 & 22 & 23 & 23 & 21 \\
\hline \multirow[t]{3}{*}{$\mathrm{TA}^{1}$} & mean & 15 & 16 & 41 & 46 & 48 & 49 & 51 \\
\hline & range & $0-37$ & $0-39$ & $11-85$ & $19-71$ & $26-70$ & $30-70$ & $31-88$ \\
\hline & $\mathrm{n}$ & 20 & 21 & 23 & 22 & 21 & 21 & 22 \\
\hline \multirow{3}{*}{$\mathrm{NH}_{4}^{+*}$} & mean & 21 & 27 & 57 & 60 & 65 & 63 & 68 \\
\hline & range & $9-57$ & $8-89$ & $22-118$ & 29-109 & $30-115$ & $29-85$ & $27-111$ \\
\hline & $\mathrm{n}$ & 19 & 20 & 22 & 21 & 21 & 21 & 22 \\
\hline \multirow{3}{*}{$\mathrm{UV}_{\mathrm{H}^{+}}{ }^{*}$} & mean & 28 & 29 & 97 & 105 & 113 & 110 & 119 \\
\hline & range & $0-74$ & $0-80$ & $33-203$ & $51-175$ & $56-174$ & $59-148$ & $60-168$ \\
\hline & $\mathrm{n}$ & 18 & 20 & 22 & 21 & 21 & 21 & 21 \\
\hline
\end{tabular}

$* \mu \mathrm{Eq} / \mathrm{min} / 1.73 \mathrm{~m}^{2}$ 
and $B$ are shown in tables I and III. All control values fell within the normal range for children of this age. Following administration of ammonium chloride in Group $\mathrm{A}, \mathrm{pH}, \mathrm{tCO}_{2}$ and $\mathrm{BE}$ in blood fell as expected with no significant change in $\mathrm{P}_{\mathrm{CO}_{2}}$. Concentrations of urea and chloride in serum rose but other electrolytes, osmolality and creatinine were unchanged. In Group $\mathrm{B}$, a considerable drop in $\mathrm{pH}$ was noted, reaching a mean of 7.27. The changes in $\mathrm{BE}, \mathrm{tCO}_{2}$ and urea were approximately double those noted in Group A with a similar rise in chloride. Other blood constituents measured were unchanged.

Urinary $\mathrm{pH}$ during control periods in both Groups $A$ and $B$ ranged from 5.1 to 7.7 (tables II and IV). Excretion of titratable acid ranged from 0 to 39 and ammonium from 8 to $89 \mu \mathrm{Eq} / \mathrm{min} / 1.73 \mathrm{~m}^{2}$. Following administration of ammonium chloride, urinary $\mathrm{pH}$ decreased to values as low as 4.65 in Group $\mathrm{A}$ and 4.55

Table III. Group B. Blood values before and three to four hours after administration of $\mathrm{NH}_{4} \mathrm{Cl}, 150 \mathrm{mEq} / \mathrm{m}^{2}$

\begin{tabular}{|c|c|c|c|c|c|c|c|c|c|c|c|c|}
\hline & \multirow[t]{2}{*}{$\mathrm{pH}$} & \multirow{2}{*}{$\begin{array}{l}\mathrm{BE} \\
\mathrm{mEq} / \mathrm{l}\end{array}$} & \multirow{2}{*}{$\begin{array}{l}\mathrm{tCO}_{2} \\
\text { mmoles/l }\end{array}$} & \multirow{2}{*}{$\begin{array}{l}\mathrm{PCO}_{2} \\
\mathrm{~mm} \mathrm{Hg}\end{array}$} & $\mathrm{Na}$ & $\mathrm{K}$ & $\mathrm{Cl}$ & $\mathrm{Ca}$ & $\mathrm{P}$ & Urea & \multirow{2}{*}{$\begin{array}{l}\text { Osm } \\
\mathrm{mOsm} / 1\end{array}$} & \multirow{2}{*}{$\begin{array}{l}\text { Creatinine } \\
\mathrm{mg} / 100 \mathrm{~m}\end{array}$} \\
\hline & & & & & \multicolumn{4}{|c|}{$\mathrm{mEq} / 1$} & \multicolumn{2}{|c|}{ mmoles/l } & & \\
\hline $\begin{array}{r}\text { Control } \\
\text { mean } \\
\text { range }\end{array}$ & $\begin{array}{l}7.41 \\
7.38 \\
7.51\end{array}$ & $\begin{array}{r}+0.2 \\
-2.0 \\
+2.5\end{array}$ & $\begin{array}{l}25.7 \\
23.0 \\
29.2\end{array}$ & $\begin{array}{l}39 \\
34 \\
45\end{array}$ & $\begin{array}{l}138 \\
131 \\
140\end{array}$ & $\begin{array}{l}4.5 \\
3.0 \\
5.2\end{array}$ & $\begin{array}{r}103 \\
96 \\
109\end{array}$ & $\begin{array}{l}4.7 \\
4.25 \\
5.25\end{array}$ & $\begin{array}{l}1.55 \\
1.3 \\
1.8\end{array}$ & $\begin{array}{l}5.5 \\
3.5 \\
7.6\end{array}$ & $\begin{array}{l}277 \\
265 \\
291\end{array}$ & $\begin{array}{l}0.66 \\
0.40 \\
1.10\end{array}$ \\
\hline $\mathrm{n}$ & 12 & 12 & 12 & 12 & 11 & 12 & 11 & 11 & 12 & 12 & 12 & 12 \\
\hline $\begin{array}{r}\text { After } \mathrm{N} \\
\text { mean } \\
\text { range }\end{array}$ & $\begin{array}{l}\mathrm{H}_{4} \mathrm{Cl} \\
7.27 * \\
7.19 \\
7.36\end{array}$ & $\begin{array}{c}-9.1 * \\
-13.5 \\
-3.5\end{array}$ & $\begin{array}{l}18.4^{*} \\
15.1 \\
21.5\end{array}$ & $\begin{array}{l}38 \\
33 \\
44\end{array}$ & $\begin{array}{l}138 \\
131 \\
148\end{array}$ & $\begin{array}{l}4.7 \\
3.3 \\
6.2\end{array}$ & $\begin{array}{l}109 * \\
101 \\
116\end{array}$ & $\begin{array}{l}4.8 \\
4.3 \\
5.5\end{array}$ & $\begin{array}{l}1.6 \\
1.3 \\
2.1\end{array}$ & $\begin{array}{l}7.4^{*} \\
5.0 \\
9.5\end{array}$ & $\begin{array}{l}290 \\
273 \\
306\end{array}$ & $\begin{array}{l}0.63 \\
0.40 \\
1.10\end{array}$ \\
\hline $\mathrm{n}$ & 35 & 32 & 35 & 35 & 30 & 34 & 33 & 33 & 31 & 35 & 32 & 32 \\
\hline
\end{tabular}

* Significantly different from control $(\mathrm{p} \leqq 0.01)$

Table IV. Group B. Urinary hydrogen ion excretion in hourly collections before and after administration of $\mathrm{NH}_{4} \mathrm{Cl}$, $150 \mathrm{mEq} / \mathrm{m}^{2}$

\begin{tabular}{|c|c|c|c|c|c|c|c|c|}
\hline & \multirow[t]{2}{*}{ Periods } & 1 & 2 & 1 & 2 & 3 & 4 & 5 \\
\hline & & \multicolumn{2}{|c|}{ Control } & \multicolumn{5}{|c|}{ After $\mathrm{NH}_{4} \mathrm{Cl}$} \\
\hline \multirow[t]{4}{*}{$\mathrm{pH}$} & mean & 6.00 & 6.50 & 5.11 & 4.92 & 4.85 & 4.85 & 4.95 \\
\hline & range & 5.1 & 5.5 & 4.7 & 4.6 & 4.6 & 4.55 & 4.6 \\
\hline & & 7.3 & 7.4 & 5.9 & 5.8 & 5.25 & 5.2 & 5.9 \\
\hline & $\mathrm{n}$ & 11 & 12 & 35 & 35 & 35 & 18 & 10 \\
\hline \multirow[t]{3}{*}{ TA* } & mean & 18 & 11 & 34 & 46 & 51 & 54 & 53 \\
\hline & range & $3-26$ & $0-23$ & $18-65$ & $27-78$ & $28-73$ & $40-77$ & $35-73$ \\
\hline & $\mathrm{n}$ & 11 & 12 & 34 & 35 & 34 & 17 & 10 \\
\hline \multirow{3}{*}{$\mathrm{NH}_{4}^{+*}$} & mean & 24 & 24 & 66 & 73 & 74 & 79 & 80 \\
\hline & range & $15-35$ & $13-45$ & $38-129$ & $33-136$ & $42-105$ & $58-106$ & $62-89$. \\
\hline & $\mathrm{n}$ & 11 & 12 & 34 & 35 & 34 & 17 & 10 \\
\hline \multirow[t]{3}{*}{$\mathrm{UV}_{\mathrm{H}}+^{*}$} & mean & 31 & 14 & 100 & 119 & 125 & 133 & 133 \\
\hline & range & $0-67$ & $0-68$ & $61-168$ & $78-181$ & $91-157$ & $100-157$ & $115-155$ \\
\hline & $\mathrm{n}$ & 11 & 12 & 34 & 35 & 34 & 17 & 10 \\
\hline
\end{tabular}

$* \mu \mathrm{Eq} / \mathrm{min} / 1.73 \mathrm{~m}^{2}$ 
Table $\mathrm{V}$. Effect of administration of $\mathrm{NH}_{4} \mathrm{Cl}$ on rates of excretion of urinary solutes

\begin{tabular}{|c|c|c|c|c|c|c|c|c|c|}
\hline & & $\mathrm{Na}$ & $\mathrm{K}$ & $\mathrm{Cl}$ & $\mathrm{Ca}$ & $\mathrm{P}$ & Urea & \multirow{2}{*}{$\begin{array}{l}\text { Greatinine } \\
\mu \mathrm{g} / \mathrm{min} / \\
1.73 \mathrm{~m}^{2}\end{array}$} & \multirow{2}{*}{$\begin{array}{l}\text { Osmotically } \\
\text { active } \\
\text { solute } \\
\mu \text { Osm } / \mathrm{min} / \\
1.73 \mathrm{~m}^{2}\end{array}$} \\
\hline & & & \multicolumn{3}{|c|}{$\mu \mathrm{Eq} / \min / 1.73 \mathrm{~m}^{2}$} & \multicolumn{2}{|c|}{$\mu \mathrm{moles} / \mathrm{min} / 1.73 \mathrm{~m}^{2}$} & & \\
\hline \multicolumn{10}{|l|}{ Group $A$} \\
\hline \multirow{4}{*}{$\begin{array}{l}\text { Control } \\
\quad(1-2)^{*} \\
\text { After } \mathrm{NH}_{4} \mathrm{Cl} \\
\quad(3-5)\end{array}$} & mean & 88 & 113 & 107 & 10 & 19 & 350 & 691 & 644 \\
\hline & range & $8-262$ & $27-271$ & $37-268$ & $0.6-33$ & $3-79$ & $151-805$ & $450-1062$ & $361-1090$ \\
\hline & mean & 197 & 138 & 314 & 15 & 41 & 492 & 874 & 1142 \\
\hline & range & $22-433$ & 23-399 & $97-602$ & $2-29$ & $14-98$ & $231-855$ & $440-1347$ & $456-2111$ \\
\hline \multicolumn{10}{|l|}{ Group $B$} \\
\hline \multirow{4}{*}{$\begin{array}{l}\text { Control } \\
\quad(1-2) \\
\text { After } \mathrm{NH}_{4} \mathrm{Cl} \\
\quad(3-5)\end{array}$} & mean & 82 & 79 & 112 & 5 & 20 & 355 & 716 & 654 \\
\hline & range & $4-210$ & $14-209$ & $10-438$ & $0.5-13$ & $4-39$ & $149-681$ & $583-1169$ & $317-1197$ \\
\hline & mean & 358 & 148 & 648 & 17 & 47 & 554 & 709 & 1580 \\
\hline & range & $100-588$ & $49-246$ & $245-1526$ & $7-31$ & $31-77$ & $205-727$ & $503-1136$ & $980-2168$ \\
\hline
\end{tabular}

* Numbers in parentheses refer to hours during which urine was collected.
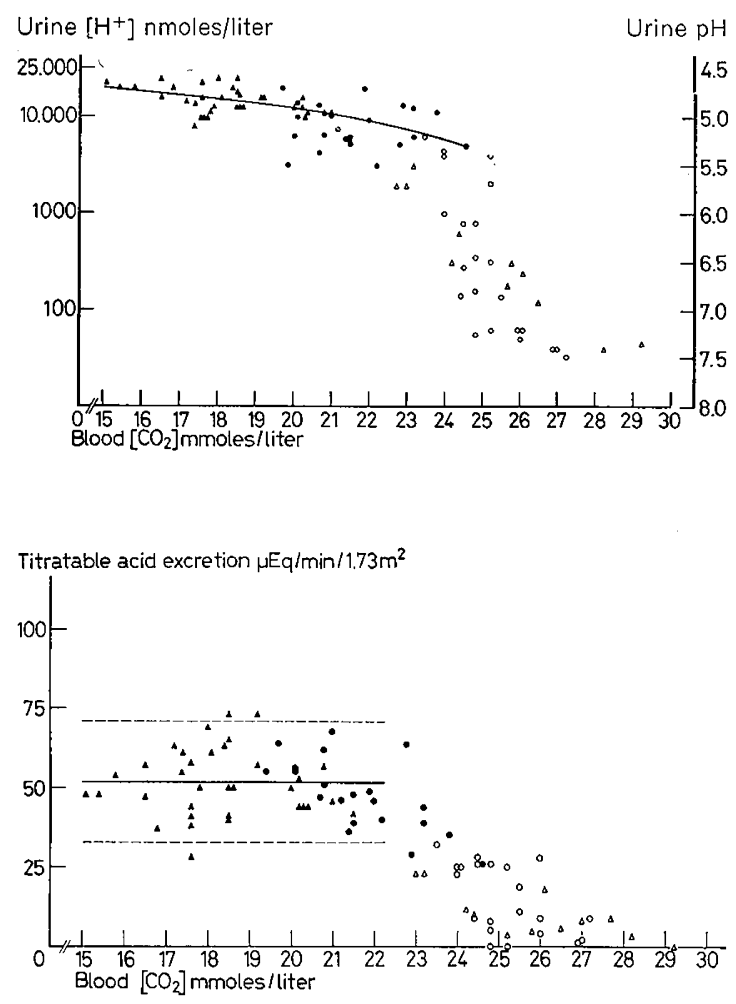

Fig.2. Excretion of titratable acid as a function of blood $\left[\mathrm{tCO}_{2}\right]$. Control periods: $\mathrm{r}=-0.49, \mathrm{p}<0.01$; after $\mathrm{NH}_{4} \mathrm{Cl}$ no regression is present. Shown are the mean and range $( \pm 2 \mathrm{SD})$ for all values with $\left[\mathrm{tCO}_{2}\right]$ below $22.5 \mathrm{mmoles} / \mathrm{l}$. Symbols are the same as in figure 1 .
Fig. 1. Urinary $\left[\mathrm{H}^{+}\right]$as a function of blood $\left[\mathrm{tCO}_{2}\right]$ in children. Two points are plotted for each subject: A control value derived from control blood and the mean of the two control urines (open symbols), and a post$\mathrm{NH}_{4} \mathrm{Cl}$ value derived from the test blood and the mean of the urines during the third, fourth and fifth hours (closed symbols). Subjects in group A are shown by circles, group $\mathrm{B}$ by triangles.

Control periods: $\mathrm{r}=-0.47, \mathrm{p}<0.001$; after $\mathrm{NH}_{4} \mathrm{Cl}$ : $\left[\mathrm{H}^{+}\right]=43348-1550\left[\mathrm{tCO}_{2}\right] ; \mathrm{r}=-0.59, \mathrm{p}<0.001 ;$ $\mathrm{b}=-1550, \mathrm{p}<0.001$. Note that this regression, although linear, is plotted here semilogarithmically.

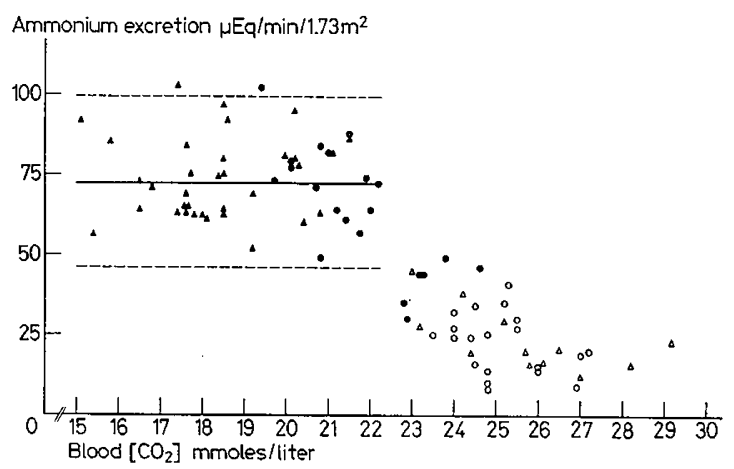

Fig.3. Excretion of ammonium as a function of blood $\left[\mathrm{tCO}_{2}\right]$. Control periods: $\mathrm{r}=-0.50, \mathrm{p}<0.001$. After $\mathrm{NH}_{4} \mathrm{Cl}$ no regression is present. Shown are the mean and range $( \pm 2 \mathrm{SD})$ for all values with $\left[\mathrm{tCO}_{2}\right]$ below $22.5 \mathrm{mmoles} / \mathrm{l}$. Symbols are the same as in figure 1 . 
in Group B. However, minimal values for some children in Group A were as high as 5.7, whereas all children in Group B achieved a urinary pH of 5.1 or less at some point during the test.

Titratable acid excretion rose as urinary $\mathrm{pH}$ fell, reaching comparable levels in both groups, approximately $50 \mu \mathrm{Eq} / \mathrm{min} / 1.73 \mathrm{~m}^{2}$ from the $2 \mathrm{nd}$ to 5 th test hours. Mean values for ammonium excretion in $\mu \mathrm{Eq} / \mathrm{min} /$ $1.73 \mathrm{~m}^{2}$ in Group A ranged from 60 to 68 , as compared to 73 to 80 in Group B. Similarly, mean values for total hydrogen ion excretion in $\mu \mathrm{Eq} / \mathrm{min} / \mathrm{m}^{2}$ in Group A ranged from 105 to 119 and in Group B from 119 to 133 .

Along with the increased rates of excretion of TA and $\mathrm{NH}_{4}^{+}$, there was an increase in rate of excretion of all urinary solutes measured (table $\mathrm{V}$ ).

The hydrogen ion clearance index, calculated with the mean values of the $3 \mathrm{rd}$, 4th and 5 th test hours, ranged in Group A from 1.36 to 4.12, with a mean of 2.66, and in Group B from 1.69 to 3.10, with a mean of 2.40 .

The relation between $\mathrm{tCO}^{2}$ of blood and urinary concentration of $\mathrm{H}^{+}$for all subjects in Groups $\mathrm{A}$ and $\mathrm{B}$ is shown in figure 1. Although levels of urinary $\mathrm{pH}$ usually considered low enough to indicate normal acidifying capacity were not produced until $\mathrm{tCO}_{2}$ of blood fell well below threshold values, progressively lower values of $\mathrm{pH}$ were observed over the entire range of $\mathrm{tCO}_{2}$ studied.

The relation between $\mathrm{tCO}_{2}$ of blood and rate of excretion of titratable acid is shown in figure 2. During control periods, an inverse correlation was present. At levels of $\mathrm{tCO}_{2}$ below $22.5 \mathrm{mmoles} / \mathrm{l}$, the rate of excretion of TA became constant. The mean rate of excretion for all values with $\mathrm{tCO}_{2}$ of blood below 22.5 mmoles/l was $52 \mu \mathrm{Eq} / \mathrm{min} / 1.73 \mathrm{~m}^{2}$ with a range $( \pm 2$ $\mathrm{SD})$ of 33 to 71 .

A similar relation between $\mathrm{tCO}_{2}$ of blood and rate of excretion of ammonium is shown in figure 3. During control periods, an inverse relation between these two measurements was observed. At levels of $\mathrm{tCO}_{2}$ below $22.5 \mathrm{mmoles} / \mathrm{l}$, maximal rates of excretion of ammonium were noted. The mean value for rate of excretion of ammonium was $73 \mu \mathrm{Eq} / \mathrm{min} / 1.73 \mathrm{~m}^{2}$ with a range $( \pm 2 \mathrm{SD})$ of 46 to 100 .

\section{Discussion}

Regulation of Urinary Acidification and Excretion of Hydrogen Ion

Although studies of bicarbonate reabsorption and excretion in infants and adults have demonstrated the close relation between concentration of bicarbonate in blood and its excretion in urine $[4,19,33]$, the effects of progressively lower concentrations of bicar- bonate in blood on urinary acidification have not been completely investigated.

The dose of ammonium chloride initially chosen in the present studies was based on dosages employed in other reports $[3,10,34]$ and was calculated to provide a maximal stimulus. After completion of the initial series in children (Group A), it was apparent that this goal had not been achieved. Several subjects appeared to excrete significantly less hydrogen ion than the remainder of the group, although the response of the group as a whole was comparable to values in children reported by others $[15,17]$.

On the basis of these results, a double dose of ammonium chloride was given in the second series of observations (Group B). In each of these subjects, urinary $\mathrm{pH}$ fell to 5.10 or less during the course of the study. The mean rates of excretion of titratable acid were the same in Groups A and B, but rates of excretion of ammonium and total hydrogen ion in Group B were significantly greater.

These results are consistent with the usual interpretation that a larger dose of ammonium chloride acts as a greater stimulus for excretion of hydrogen ion by the kidney. However, when urinary acidification and rates of excretion of $\mathrm{TA}$ and $\mathrm{NH}_{4}$ were examined as functions of $\mathrm{tCO}_{2}$ of blood, it was apparent that the size of the dose of $\mathrm{NH}_{4} \mathrm{Cl}$ played no role.

During control periods (figs. 1-3), when $\mathrm{tCO}_{2}$ ranged from 23 to 29 mmoles/l, significant correlations were present between $\mathrm{tCO}_{2}$ of blood and urinary hydrogen ion concentration, rate of excretion of $\mathrm{TA}$ and rate of excretion of ammonium. Following ingestion of $\mathrm{NH}_{4} \mathrm{Cl}$, there was still a significant correlation between urinary hydrogen ion concentration and $\mathrm{tCO}_{2}$ of blood. In contrast, when $\mathrm{tCO}_{2}$ fell several millimoles below the threshold, excretion of hydrogen ion in the form of TA and $\mathrm{NH}_{4}$ reached a plateau. Thus, the apparent difference observed in mean response of Groups $\mathrm{A}$ and $\mathrm{B}$ was due to an inadequate depression of $\mathrm{tCO}_{2}$ in blood in six subjects of Group A; at comparable levels of $\mathrm{tCO}_{2}$, no differences in response were noted. Theoretically, the larger dose of $\mathrm{NH}_{4} \mathrm{Cl}$ might have resulted in higher rates of excretion of ammonium due to increased production of glutamine and provision of additional substrate [2]. No such difference in rate of excretion of ammonium was noted, although the rate of excretion of urea in Group B was greater than that in Group A.

These data are interpreted as demonstrating the importance of the level of $\mathrm{tCO}_{2}$ of blood, or more precisely, the concentration of bicarbonate in glomerular filtrate, in stimulating urinary acidification mechanisms as well as in control of excretion of bicarbonate [18-20]. The rate of excretion of titratable acid depends upon availability of urinary buffer, particularly 
phosphate, and urinary $\mathrm{pH}[30]$. Acute changes in the rate of excretion of ammonium are dependent on changes in urinary $\mathrm{pH}$ and the rate of urine flow [12, 16]. When concentrations of bicarbonate in blood are above the renal plasma threshold, bicarbonate is incompletely reabsorbed; hydrogen ion secreted along the entire length of the nephron is utilized in bicarbonate reabsorption, and bicarbonate is excreted into the urine. At bicarbonate levels in blood just at the threshold, the urine is free of bicarbonate, but almost all hydrogen ion secreted is still utilized in bicarbonate reabsorption; urinary $\mathrm{pH}$ is lowered only slightly below that of plasma and little $\mathrm{TA}$ and $\mathrm{NH}_{4}^{+}$are present in urine. As bicarbonate concentration in blood falls below the threshold, more hydrogen ion appears in urine, but only when blood bicarbonate is well below threshold levels is sufficient tubular $\mathrm{H}^{+}$available to cause maximal urinary acidification and thus in turn formation of TA and $\mathrm{NH}_{4}$. Rate of excretion of hydrogen ion reaches a plateau, despite further depression of bicarbonate in blood, when urinary buffers are saturated and there is maximal diversion of tubular $\mathrm{NH}_{4}^{+}$ into urine.

Although the present investigations suggest that the concentration of bicarbonate in the glomerular filtrate is the most important factor controlling renal excretion of hydrogen ion during acute metabolic acidosis, in other circumstances, variation in rate of excretion of hydrogen ion occurs in the apparent absence of changes in $\mathrm{pH}$ or bicarbonate of blood. However, this may be mediated through the same mechanism by a change in the bicarbonate threshold, similar to the effect on acid excretion of variation in the carbon dioxide tension of blood [1, 23, 24].

The concept of a dynamic balance between the concentration of bicarbonate in the glomerular filtrate and the level of the bicarbonate threshold must be considered. A change in either will have a marked effect on the rate of delivery of bicarbonate into the distal tubule and, thus, on the rate of hydrogen ion excretion. An effect of potassium deficiency and extracellular volume expansion on proximal tubular reabsorption of bicarbonate has been demonstrated $[13,21]$. Similarly, both the degree to which the kidney is stimulated to reabsorb sodium and the ratio of sodium to chloride in the glomerular filtrate influence the level of the threshold [31]. The change in bicarbonate threshold that occurs with a change in the rate of excretion of nonreabsorbable anions, such as sulfate [22], may explain part of the variation in hydrogen ion excretion that occurs with dietary changes [14].

Thus, the precise manner in which the kidney maintains systemic acid-base balance in health may be related to slight variation in the bicarbonate threshold, whereas in acutely induced metabolic acidosis with no change in threshold, the primary factor appears to be the decreased concentration of bicarbonate in the glomerular filtrate. In chronic acidosis there is, in addition, an adaptation in tubular production of ammonia [29], which may relate to intracellular acidosis.

\section{Clinical Assessment of Acidifying Capacity}

It is apparent from these results that assessment of renal acidifying mechanisms requires administration of a substance which will produce maximal urinary acidification. This can be accomplished by administration of a nonreabsorbable anion, or, more physiologically, by administration of sufficient ammonium chloride or other acidifying substance to depress $\mathrm{tCO}_{2}$ of blood to levels well below the renal threshold.

The results of the present studies, as well as those of Wrong and Davies $[3,34]$, indicate that the short test provides an adequate physiologic assessment of acidifying mechanisms, even though it does not assess ammonium adaptation during chronic acidosis. However, normal rates of excretion of ammonium during acute acidosis with deficient excretion of ammonium during chronic acidosis has not been described.

The hydrogen ion clearance index was proposed by Elkinton and Associates [5] in an attempt to relate rate of excretion of hydrogen ion in urine to the concentration of hydrogen ion in blood. Although this index has had widespread application, its physiologic validity must be questioned. Correcting rates of excretion of hydrogen ion for concentration of total $\mathrm{CO}_{2}$ in blood presumes that there is a fixed relation between these two measurements. Examination of the data presented by ELKINTON et al. [5], however, reveals no regression of TA, $\mathrm{NH}_{4}^{+}$or total hydrogen ion with $\mathrm{tCO}_{2}$ in blood following administration of $\mathrm{NH}_{4} \mathrm{Cl}$. In the present study (fig. 4), urinary excretion of total hydrogen ion is plotted as a function of blood $\mathrm{tCO}_{2}$.

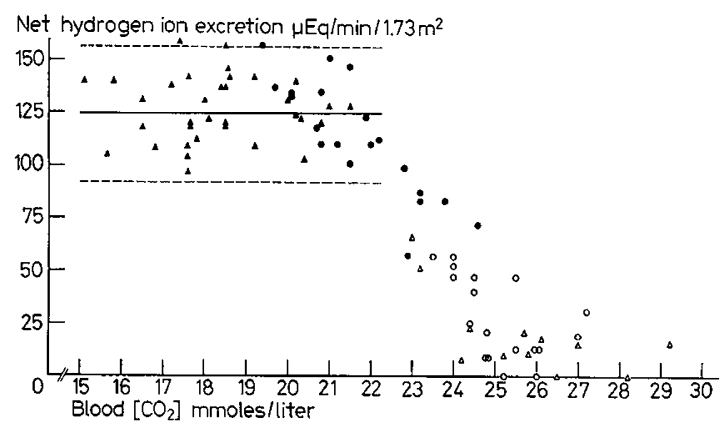

Fig.4. Net excretion of hydrogen ion as a function of blood $\left[\mathrm{tCO}_{2}\right]$. Control periods: $\mathrm{r}=-0.55, \mathrm{p}<0.001$. After $\mathrm{NH}_{4} \mathrm{Cl}$ no regression is present. Shown are the mean and range $( \pm 2 \mathrm{SD})$ for all values with $\left[\mathrm{tCO}_{2}\right]$ below $22.5 \mathrm{mmoles} / \mathrm{l}$. Symbols are the same as in figure 1 . 
Hydrogen ion excretion, negligible at $\mathrm{tCO}_{2}$ levels of $26 \mathrm{mmoles} / \mathrm{l}$ or more increases steadily as $\mathrm{tCO}_{2}$ falls to values below the threshold. The rate of excretion then reaches maximal levels, despite further reduction in $\mathrm{tCO}_{2}$. Consequently, the hydrogen ion clearance index in a given subject would be much higher if measured at a $\mathrm{tCO}_{2}$ in blood of $20 \mathrm{mmoles} / 1$, for example, than if it were measured at $15 \mathrm{mmoles} / \mathrm{l}$. This effect can be seen in comparing Group A with Group B. As a consequence of the lower values of $\mathrm{tCO}_{2}$ produced in children in Group B, their hydrogen ion clearance index was lower, suggesting incorrectly that these subjects performed less well than those in Group A.

Thus, the hydrogen ion clearance index is valid only over the range of $\mathrm{tCO}_{2}$ in blood in which there is a linear relation with rate of excretion of hydrogen ion, i.e. from the range of normal concentration down to levels around the threshold. Over this range of $\mathrm{tCO}_{2}$, however, urinary hydrogen ion excretion is not maximal and the range of normal is great. Rather than using the hydrogen ion clearance index, therefore, acidification should be evaluated with $\mathrm{tCO}_{2}$ in blood several millimoles below the threshold, assuring a maximal response and permitting direct comparison with normal subjects. It is obvious that arbitrary, 'standard' doses of ammonium chloride may be either too large or too small for this purpose. The proper dose for a given subject can be calculated on the basis of the $\mathrm{CO}_{2}$ content of blood, assuming distribution of administered $\mathrm{H}^{+}$throughout body water. In subjects with a normal level of bicarbonate threshold, $\mathrm{tCO}_{2}$ in blood should be depressed at least to $17-18 \mathrm{mmoles} / \mathrm{l}$ in infants [4] and 20-21 mmoles/l in older children. If an abnormal bicarbonate threshold is present the dose must be adjusted accordingly [26, 27].

\section{Summary}

Observations of the renal response of children to administration of ammonium chloride support the hypothesis that the concentration of bicarbonate in glomerular filtrate, together with the level of the bicarbonate threshold, plays a major role in the regulation of renal excretion of hydrogen ion. An inverse relation was demonstrated between the total $\mathrm{CO}_{2}$ content of blood and the concentration of hydrogen ion in urine. Rates of excretion of titratable acid and ammonium increased as concentration of total $\mathrm{CO}_{2}$ in blood fell below normal levels; both rates reached a plateau, however, when total $\mathrm{CO}_{2}$ reached concentrations a few millimoles below the renal bicarbonate threshold.

These results indicate that the necessary condition for assessing maximal acidifying capacity during metabolic acidosis is that the blood bicarbonate concentra- tion be several millimoles below the renal bicarbonate threshold; the use of a 'standardized' dose of ammonium chloride does not assure a maximum response. Evidence is presented that calculation of the hydrogen ion clearance index does not provide a physiologically meaningful assessment of urinary acidification.

\section{References and Notes}

1. Brazeau, P. and Gilman, A.: Effect of plasma $\mathrm{CO}_{2}$ tension on renal tubular reabsorption of bicarbonate. Amer.J. Physiol. 175: 33-38 (1953).

2. Canessa-Fischer, M.; Shalhoub, R.; Glabman, S.; DeHaAs, J. and PitTs, R. F.: Effects of infusions of ammonia, amides, and amino acids on excretion of ammonia. Amer.J. Physiol. 204: 192-196 (1963).

3. Davies, H.E.F. and Wrong, O. : Acidity of urine and excretion of ammonium in renal disease. A preliminary report. Lancet $i i$ : 625 (1957).

4. Edelmann, C. M., Jr.; Rodriguez Soriano, J.; Boichis, H.; Gruskin, A.B. and Acosta, M.I.: Renal bicarbonate reabsorption and hydrogen ion excretion in normal infants. J.clin. Invest. 46: 1309-1317 (1967).

5. Elkinton, J.R.; Huth, E.J.; Webster, G. D., Jr. and MaCance, R.A.: The renal excretion of hydrogen ion in renal tubular acidosis. I. Quantitative assessment of the response to ammonium chloride as an acid load. Amer. J. Med. 29: 554-575 (1960).

6. Følling, A.: On the mechanism of ammonium chloride acidosis. Acta med.scand. 71: 221-279 (1929).

7. Fomon, S.J.; Harris, D.M. and Jensen, R.L.: Acidification of the urine by infants fed human milk and whole cow's milk. Pediatrics 23: 113-119 (1959).

8. Gamble, J.L.; Blackfan, K.D. and Hamilton, B.: A study of the diuretic action of acid producing salts. J.clin. Invest. 1: 359-388 (1925).

9. Gordon, H.H.; MaNamara, H. and Benjamin, H.R.: The response of young infants to ingestion of ammonium chloride. Pediatrics 2: 290-302 (1948).

10. Greder, G. et Guttmann, F. M. : Le test d'acidification urinaire au chlorure d'ammonium, complément à l'étude des fonctions rénales. Helv. med. Acta 29: 1-37 (1962).

11. HALdANe, J.B.S.: Experiments on the regulation of the blood's alkalinity. J.Physiol. 55: 265-275 (1921).

12. Huxus, A. G. and Reid, E. L.: Renal ammonia balance. A kinetic treatment. Nephron 3: 221-256 (1966).

13. Kunau, R.; Frick, A.; Regtor, F. G. and Seldin, 
D.W.: Effect of extracellular volume expansion, $\mathrm{K}+$ deficiency and $\mathrm{P}_{\mathrm{CO}_{2}}$ on bicarbonate reabsorption in the rat kidney. Clin. Res. 14: 380 (1966).

14. Lennon, E.J.; Lemann, J., Jr. and Relman, A.S.: The effect of phosphoprotein on acid balance in normal subjects. J. clin. Invest. 41: 637-645 (1962).

15. Lestradet, H.; Correa, G.E. G. et Broyer, M.: L'exploration de la fonction d'acidification du tubule rénal par une épreuve courte utilisant une surcharge intraveineuse du chlorydrate de L-Arginine. Rev. franç. Etud. clin. biol. 9: 885-892 (1964).

16. OrLofF, J. and Berliner, R.W.: The mechanism of the excretion of ammonia in the dog. J.clin. Invest. 35: 223-235 (1956).

17. Peonides, A.; Levin, B. and Young, W.F.: The renal excretion of hydrogen ion in infants and children. Arch. Dis. Childh. 40: 33-39 (1965).

18. Pitts, R.F.: Physiology of the kidney and body fluids, p. 163 (Year Book Medical Publishers, Chicago 1963).

19. Prtts, R.F.; Ayer, J.L. and Schiess, W.A.: The renal regulation of acid-base balance in man. III. The reabsorption and excretion of bicarbonate. J. clin. Invest. 28: 35-44 (1949).

20. Pitts, R. F.; Lotspeich, W.D.; Schiess, W.A. and AYER, J.L.: The renal regulation of acid-base balance in man. I. The nature of the mechanism for acidifying the urine. J.clin. Invest. 27: 48-56 (1948).

21. Regtor, F.G., Jr.; Bloomer, H.A. and Seldin, D.W.: Effect of potassium deficiency on the reabsorption of bicarbonate in the proximal tubule of the rat kidney. J. clin. Invest. 43: 1976-1982 (1964).

22. Rector, F. C., Jr. and Seldin, D.W.: Influence of unreabsorbed anions on renal threshold and Tm for bicarbonate. Amer.J.Physiol. 202: 313-324 (1962).

23. Regtor, F. G., Jr.; Seldin, D.W.; Roberts, A. D., Jr. and Smith, J.S.: The role of plasma $\mathrm{CO}_{2}$ tension and carbonic anhydrase activity in the renal reabsorption of bicarbonate. J.clin. Invest. 39: 1706-1721 (1960).

24. Relman, A.S.; Etsten, B. and Schwartz, W.B.: The regulation of renal bicarbonate reabsorption by plasma carbon dioxide tension. J. clin. Invest. 32: 972-977 (1953).

25. Reynolds, T.B.: Observations on the pathogenesis of renal tubular acidosis. Amer. J. Med. 25: 503515 (1958).

26. Rodriguez Soriano, J.; Boichis, H.; Stark, H. and Edelmann, C. M., Jr.: Proximal renal tubular acidosis. A defect in bicarbonate reabsorption with normal urinary acidification. Pediat. Res.1: 81-98 (1967).

27. Rodriguez Soriano, J.; Borchis, H. and EdelMANN, C.M., Jr.: Bicarbonate reabsorption and hydrogen ion excretion in children with renal tubular acidosis. J. Pediat. 71: 802-818 (1967).

28. Rubin, M.I.; Galgagno, P.L. and Ruben, B.L.: Renal excretion of hydrogen ions. A defense against acidosis in premature infants. J. Pediat. 59: 848-860 (1961).

29. Sartorius, O.W.; Roemmelt, J.G. and Pitts, R.F.: Renal regulation of acid-base balance in man. IV.The nature of the renal compensations in ammonium chloride acidosis. J. clin. Invest. 28: 423-439 (1949).

30. Schiess, W.A.; Ayer, J. L.; Lotspeich, W.D. and Pitts, R. F.: The renal regulation of acid-base balance in man. II. Factors affecting the excretion of titratable acid by the normal human subject. J. clin. Invest. 27: 57-64 (1948).

31. Schwartz, W.B. and Relman, A.S.: Effects of electrolyte disorders on renal structure and function. New Engl.J. Med. 276: 383-389 and 452-458 (1967).

32. SNEDECOR, G.W.: Statistical methods applied to experiments in agriculture and biology, 5th ed. (Iowa State University Press, Ames 1956).

33. Tudvad, F.; MaNamara, H. and Barnett, H. L. : Renal response of premature infants to administration of bicarbonate and potassium. Pediatrics 13: 4-16 (1954).

34. Wrong, O. and Davies, H.E.F.: The excretion of acid in renal disease. Quart.J. Med. 28: 249-313 (1959).

35. The authors gratefully acknowledge the important contributions of the nursing staff of the Renal Unit, under the supervision of EDNA, J. FRANcIs, RN, and of the technical staff, under the direction of Amy B. Martinez, Research Assistant.

36. Supported in part by USPHS Research Grants 5 T $01 \mathrm{HE} 05267$ and HE 05561 from the National Heart Institute; the Kidney Foundation of New York; and the Sylvan League, Inc.

37. Edelmann, C. M., Jr., M.D., Associate Professor of Pediatrics, Albert Einstein College of Medicine, 1300 Morris Park Avenue, Bronx, N.Y. 10461 (USA). Recipient of Research Gareer Development Award, National Institute of Child Health and Human Development (1-K3-HD 19369). 